\title{
Personal uniqueness therapy: Living with an inner ideal
}

\author{
Leonid Z. Levit \\ Ph.D., Assistant Professor, Centre for Psychological Health and Education, Minsk, Belarus
}

Email address:

leolev44@tut.by

\section{To site this article:}

Leonid Z. Levit. Personal Uniqueness Therapy: Living with an Inner Ideal. American Journal of Applied Psychology. Vol. 3, No. 1, 2014, pp. 1-7. doi: 10.11648/j.ajap.20140301.11

\begin{abstract}
The article under consideration represents a new system of psychotherapy and self-therapy - Personal Uniqueness Therapy (PUT). It is based on the author's Person-oriented conception of happiness (POCH), particularly its "PU" system. The motivating force of inner ideals is applied in the process of therapy. The author demonstrates PUT distinctions from all other systems of therapy which have a surface resemblance to it. A client is taught to feel, get in contact and gradually broaden her ideal part that helps her to initiate the coping process during distress and gradually overcome external difficulties. A vignette concerning the application of the main PUT techniques in the author's work with a depressive client is adduced.
\end{abstract}

Keywords: Positive Psychology, Psychotherapy, Personal Uniqueness, Egoism, the Ideal, Meaning, Self-Realization

What's the use for a man if he conquers the whole world but looses himself?

Jesus Christ

\section{Person-Oriented Conception of Happiness: Introduction and Explanation}

In the years 2006 - 2012 the author (Leonid Levit) has elaborated a synthesizing conception of self-realization and happiness, which is based on the ideas of the systemic approach and combines biological, psychological, social and spiritual (the highest) levels of individual life and activity. The results of our seven-year work on the problem are summarized in five monographs [1-5] and articles [6-11].

Our Person-oriented conception of happiness $(\mathrm{POCH})$ belongs to eudaimonic group of theories, which deal with a person's realization of her unique potential. It represents the interaction of two systems - «Personal Uniqueness» (PU) and «Egoism» (EG). The original design of the new theory was based on the necessity to discriminate between the concepts belonging to substantial issues of self-realization (e.g., the Ancient Greek concept of daimon, the Jungian Self, the Inner Self of C. Rogers etc.) and its more dynamic functional forces (the Maslowian self-actualization, Freud's sublimation etc.).

Moving bottom-up (see fig. 1), let us examine the main components of POCH. Each system consists of four levels.
Both systems develop from one level to the higher one, thus changing the interaction of horizontally corresponding levels.

Firstly let's briefly describe the Personal Uniqueness system (the left one). PU is somewhat analogous to daimon in its classical meaning or personal potential in humanistic comprehension. Personal Uniqueness represents a synthesis of individual talents, gifts and potentials ("U") with the personal components ("P") that facilitates its application in "appropriate" activity (assurance, persistence, etc.). The latter ("P") rarely have an inborn character and are associated with an adult personality rather than the former ("U').

At its first biological level it is represented by the letter «U» (Uniqueness), which implicates a kind of natural gift, the inherited disposition of individual. At the next, second level which is usually associated with person's youth, the disposition gradually changes into abilities and begins to actualize. At that very period, an individual usually has some difficulties due to the shortage of her personal maturity and responsibility. The situation is gradually being corrected at the third stage, when the person acquires motivational components of self-regulation ( $\langle\mathrm{P} »)$ which help to overcome the obstacles inside specific activity and persistently move towards the attainment of personal goals. At the final fourth stage (if it comes) we can see the mature Personal Uniqueness. Its realization provides all the effects, which were discussed in numerous works on eudaimonia [12-14].

Now let's describe the «Egoism» (EG) system. The biological («body») level of our model (EG-1) is represented 
by the concept of Health, which we understand primarily as the absence of essential body problems in the course of psychological self-realization. The necessity of its inclusion is determined by the importance of biological, genetic premises of man's egoism as well as a number of works showing beneficial effects of person's health on her self-realization and happiness achievement [15-17]. As for the concept of Basic Egoism (EG-2), the inborn property which is common to humans and other living creatures we place at Level 2. EG-2 is responsible for self-protection and survival of the species, along with satisfying two basic instincts (the need for food and sexuality), that bring fundamental pleasures to an individual $[18,19]$.

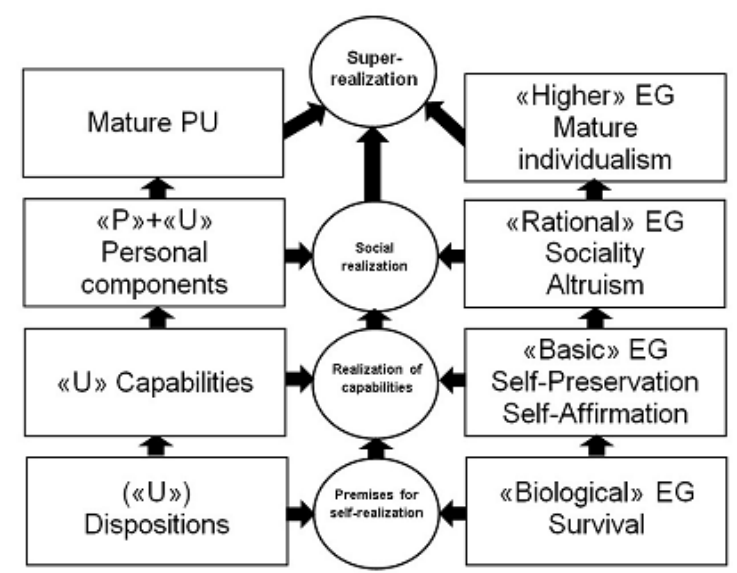

Figure 1. Scheme of $P O C H$.

Moving further up from L2 to L3, Basic EG gradually transforms into Rational Egoism (REG), that includes more intellectual, regulatory, and (if necessary) reflexive components. Until being totally reoriented towards PU actualization REG is responsible for productive activity at the social level and "human" pleasures (artistic, altruistic, monetary etc.) $[18,19]$.

Finally, the fourth level is associated with higher forms of egoism (mature individualism), when a person, having surmounted the three previous stages, makes the deliberate decision to devote his life to self-realization, taking his Personal Uniqueness as the highest value $[11,20]$. Here we can see the overcoming of the lower, Basic Egoism with its pleasure principle and serious reorientation of Rational Egoism. While REG organizes the social environment for an individual, his Higher Egoism of Level 4 creates the best conditions for PU actualization.

Thus, we argue that cohesive interaction of EG-4 and PU-4 brings self-realization, happiness and full-fledged human life. «Egoism» system at its higher levels is the best partner for «Personal Uniqueness» system since it accomplishes protective, intellectual and motivating functions in the process of her actualization, being on the outside of the PU activity. In the last three years we have published quite a lot of articles as well as some monographs on the issue.

\section{Personal Uniqueness Therapy}

Modern psychotherapy numbers about 400 systems and methods [21]. We have decided to offer the reader's attention one more - "Personal Uniqueness Therapy" (PUT) which is based on the ideas of our theoretical conception. A client learns by degrees to get in contact with and be aware of her Personal Uniqueness (PU) as her "ideal" part which not only determines her life designation but helps to cope with external distress [22,23]. In PUT we use only one of the two main POCH systems (PU) taken out of its interaction with the "EG" system. That's why this article deals only with the improvement of a person's inner state, not her (future) self-realization.

Almost every person can remember how she "switched" to some other area of her life (for example, hobby, sport or family life) while being in the period of crisis or distress. Consequently she found the resources which helped her to endure the troubles and cope with them. We assert that the notion of Personal Uniqueness represents the most reliable support in such cases for two reasons. First of all, it is the best, the ideal part of personality - that's why the contact with it can be the most fruitful in hard times. Secondly, Personal Uniqueness, being an inborn formation, is already located inside the person. It means that PU remains unimpaired by any external event. Thus a person with a distinct feeling of her Personal Uniqueness gets an opportunity to shelter in her own cozy "sanctuary" and rehabilitate her mental equilibrium. Such a feeling should strengthen just in contrast to external problems which can hardly be overcome by direct actions.

The above mentioned considerations determine the importance of PUT elaboration and application. Actually, almost any client is able to understand and become inspired with the idea of her own uniqueness which can withstand external stresses. Thus she gets an easy access to her "inner resourceful states" and enters a new kind of therapy with positive feelings. Commonly, quite a lot of clients have a negative experience concerning the preceding therapeutic interventions which didn't take into account their individual virtues.

PUT represents the psychotherapy (and self-therapy later) which helps an "outer-directed" person to get in contact with herself. We can say that PUT ideas are somehow close to positive thinking, which is turned inwards: "Everything will be good - but inside me, not in the outer world which can hardly be basically predicted or controlled". Instead of searching for the "authorities" and follow their recommendations throughout her life, a person begins to learn from inside - from her ideal part.

PUT gives the therapist a good opportunity to assess client's motivation and readiness for that specific psychotherapy rather quickly. The distinctiveness of Personal Uniqueness inner signals (the sensation of warmth, positive experience of "inner treasure", affirmative answers coming from the inside, corresponding visual images, reports about one's own potential and unique achievements 
etc.) is considered to be a good prognostic sign for the future collaboration.

As a rule, PUT is used with (and by) more educated clients familiar with the notions of "personality" and the "inner ideal". The therapy is applied in cases where they (their "EG" system) cannot change the unfavorable (external) situation. Serenity and humility (in accordance with the second part of R. Nibur's prayer) thus become the best choice for a while. The attention is turned inwards to the retained resources and PU in particular. Being in contact with the ideal part facilitates the beginning of coping processes, which mean gradual transition from negative aspects of living to positive ones: "Now I feel myself bad, but my ideal Personal Uniqueness is still with me. I shall be able to actualize it in future and make my life happier".

Our perennial work in the sphere of psychology and psychotherapy has shown, that delineation and subsequent contact of an individual with the best part of herself - her "inner treasure" which always stays with her, helps to live through the periods of life crises and distresses more easily [22].

Let's remember that Socrates, one of the founders of eudaimonic tradition in the Ancient Greek philosophy, considered the essence of man's love in its aspiration towards highest values, particularly to his daimon, which represents man's inner excellence [24]. So PU is to some extent rather close to daimon.

Being the "ideal" part of an individual, Personal Uniqueness can also to some extent remind us of the Plato's theory. As O. Huxley puts it, Platonic views form the foundation of the psychology which finds in human soul anything similar to divine reality or even identical to it [25].

\section{PUT: Comparative Analysis}

The concept of Personal Uniqueness distinguishes from the Rogerian "ideal Self" [26] substantially. The last term identifies an ideal person whom the client would like to become but still hasn't. Similar to inborn daimon, PU is already inside a person's psyche, her unconscious part. A client should discover his PU and live in accordance with it: "Know thyself and become who you are". That's why PU doesn't contain a hardly surmountable gap between present and future states of a person. The necessary premises exist from birth; their disclosure and further productive realization become client's main task. In distinction to traditional humanistic and positive psychology, we do not consider human nature to be totally intrinsically good, but we state the presence of the best, ideal part inside it Personal Uniqueness.

It goes without saying, PU has nothing in common with Freudian Superego [27], because Personal Uniqueness emphasizes creative and resourceful states of a person rather than her ability to suit social norms and demands. At the same time we can find some common features between PUT (turning to the ideal part of oneself) and sublimation mechanism, which implies reorientation of psychic energy on some "higher" purpose. Such process intensifies inner activity and thus enables a person to attain a sort of independence from harmful environmental and social effects.

At the same time PUT is not a synonym of isolation. The latter one is usually interpreted as psychological defense, mainly practiced by schizoid personalities [28]. Very often, schizoids have deeply antagonistic inner parts of themselves which are usually in conflict, while PUT presupposes "friendly" inner space with an ideal part inside it. Schizoid isolation usually means an exit into the world of abstract fantasies, while PUT concentrates attention on a person's real and best qualities, being liable to future actualization in the external world.

In the frame of psychological defense, the idea of one's Personal Uniqueness can be regarded as double "superdefence" which can outline the boundaries not only between inner and external world but also inside a person between the ideal PU, invulnerable for immediate crisis and other parts of personality fighting with that crisis.

The concept of Personal Uniqueness can be regarded as the best positive counterbalance to external troubles because it's hardly possible for a client to search for meaning and "good" aspects in the tragedy that has just happened to her. Such "positive" advices for example can be found in N. Peseschkian's psychotherapy [29]. Therefore a person can temporarily turn to her inner ideal, thus preserving relative mental balance and resources for fighting with difficulties. The client reaches a kind of separation off the hurting external situation. The energy that was previously wasted in vain, becomes accessible for inner needs - due to outside crisis as well.

The well-known historic events confirm our point of view. For example, Hebrews who were cruelly persecuted for many times in history could find inner strength for survival and self-esteem due to their religious feeling of "uniqueness", of being "chosen" by God. In such circumstances, the "inner treasure" of PU is extremely compact - it can always be taken with oneself in times of trouble. Besides, it cannot be seen by strangers and therefore can't become an object of their hostile actions. The abovementioned feature clearly shows superiority of the higher levels of human psyche towards the lower ones namely to the environment, the source of crises and potential distress.

At first glance one might notice some resemblance between PUT ideas and narcissism. Let's point out that the notion of Personal Uniqueness implies only one separate "part", not the whole person. This ideal part is still hidden in the client's unconscious (at the beginning of PUT) and great labor is required for the person to uncover and realize it. That's why the subject has no perfunctory narcissistic conceit and doesn't need any admiration from other people. She possesses no narcissistic envy at anybody since she is satisfied with the feeling of her own uniqueness. The individual is advised to undertake efforts for the sake of PU development and its (future) actualization (which is 
untypical for narcissus). Some more dignity and self-esteem which appear in the process of PUT is a good "antidote" for depression during any distress.

Our recent research $[5,30]$ has shown one moderate positive correlation between the Personal Uniqueness Scale (ELU Inquiry elaborated by the author) and the third Scale ("Belief in one's own uniqueness") of the inquiry which diagnoses narcissistic personality traits [31]. Only one significant moderate correlation with nine "narcissistic" scales means a clear distinction between the two constructs.

At least, as we know, individuals with narcissistic traits have no inclination for committing suicide - presumably, due to their grandiose Self [30]. That's why a small portion of "narcissism" may be useful for any person in difficult situations. In contradistinction to the positive mantra "I can (do everything)", a person with distinct PU says: "I can (do something important from my perspective) because I possess my Personal Uniqueness, my inner resources". In our opinion, PUT may be useful exactly to narcissus inasmuch as she suffers from inner emptiness and lack of self-respect. It is important, the client has to pay some effort in order to get in contact with her PU and actualize it later. Such features of PUT have nothing in common with narcissism.

So far as we can see, all the abovementioned constructs adjacent to PU have some surface resemblance to its meaning. Each of them possesses some negative aspect and so can hardly be used for positive therapy purpose. Even freudian sublimation which can lead to creative self-realization is accomplished in psychoanalytic frame not for her own sake but as a result of negative motivation aimed at a person's avoidance of the society sanctions in case of the open drives reveal. The existential perspective also "tends to focus on learning to live with the dark side of the human condition, such as suffering, meaninglessness, loneliness and death..." [32]. Therefore we regard PUT as a new (perhaps the first) system of really positive psychotherapynot only because it stems from our theoretical conception $(\mathrm{POCH})$ but also owing to the ideal nature of the Personal Uniqueness concept. PU represents the guiding line not only for coping with life difficulties but the reference point for personal development and self-fulfillment as well. The latter points might also be successfully accomplished due to the well-known inducing power of inner ideals.

\section{Religion and Positive Psychology}

In our opinion, PUT can be successfully applied with religious people as well. The early Christian movements emphasized the idea according to which every person possesses the divine "core" deep inside her soul [33]. Therefore, a religious person can establish transcendence and strengthen connectedness with God due to her PU improvement. One's Personal Uniqueness is the very appropriate object for spiritual practices as long as it 1) is located inside a person that makes easier for her to search and "discover" it and 2) it is ideal and therefore towers above everyday fuss. In such interpretation, the believer simply has to hear the inner call of her own "divine strength" and live in accordance with it.

During the hard periods in life, the believer can adhere not only to God but to her own Personal Uniqueness: "Notwithstanding all the troubles, God didn't take my PU away. I can continue to seek God in devotion through my PU. It means that God is still with me since I am a good (righteous) person".

That's why we can turn over the quotation placed at the beginning of the article: an individual has nothing to be afraid of, if he hasn't lost himself. A man hasn't conquered the world, but the world also can not conquer the spiritual core of a man. Nobody is able to take away his Personal Uniqueness - the "inner treasure" of his soul. So, a client also learns to value a "gift" that she already possesses instead of a feverish pursuit of more and more goods and pleasures. Such mental orientation greatly decreases or absolutely excludes the neurotic feeling of a gap between the wanted and the real state of things.

The most consistent PU follower could even create a kind of proper religion in which her Personal Uniqueness was considered to be the ultimate representative of higher mentality. In no way we want to propagate such possibility as panacea; we simply demonstrate the broad range of ideas implicitly present in our system.

Therefore the above mentioned "serenity prayer" in the frame of both POCH systems can be interpreted as follows: we actualize our Personal Uniqueness with the help of Higher Egoism (the $4^{\text {th }}$ level of the model) when we can change the situation in our favor. And we simply "hold on" to our PU (or to the idea of our PU) in hard and unchangeable circumstances which should be accepted. In the first case we fulfill the creative values; in the second the attitude values, thus preserving the meaning of our life [34]. As long as we have discovered a number of significant positive correlations between the "meaning" scales and the PU scale [5] we assume the possibility of life meaning attainment through the very Personal Uniqueness realization.

It goes without saying, PUT (as well as POCH) has much in common with the ideas and methods of positive psychology. Let's take only one example from $M$. Seligman's book: "Therapists reported me that getting their patients in touch with their strengths, rather than just trying to correct their weaknesses was particularly beneficial" [35]. M. Seligman also enumerates the hallmarks of "signature strength" [pp. 38 - 39] which are already being employed in our practical work - primarily, in the so called "Eudaimonic Training" (ET), elaborated several years ago [3, 5, 22, 36].

ET can be regarded as a very good facilitating instrument for PU uncovering if it foregoes PUT. One of our investigations conducted in 2011 demonstrates the average 50-percent increase in PU scale (ZULUREG Inquiry, the ELU predecessor) [37] one month after ET termination in comparison with the results shown at the beginning of ET [3, 20,36]. Unfortunately, ET has rather a "learning" character 
and therefore is usually studied by healthy pupils, while PUT is applied mainly in psychotherapeutic purposes. That's why both contingents rarely intersect with each other.

The PUT ideas properly applied can do no harm even to psychotics in the remission stage. In this case, we can name the "best", "healthy" part of a patient's personality her PU which should be strengthened and developed in everyday activity. It goes without saying, PUT can be also chosen as an auxiliary means of help.

\section{PUT Application: A Case of Depressive Disorder}

Let us give an example of the main PUT techniques which are easy to master. The client N. was a 36 years old female, married, no children, a musician in the orchestra (violin). Previously she was hospitalized twice to the neuroses department of the 10th state clinic in Minsk. She had to abandon her work as a result of strong pains in her hands during performance and some other situations associated with stress. Depressive disorder was diagnosed and she was treated with several courses of antidepressants which didn't much alleviate her state. At our first session she scored 18 points in Beck Depression Inquiry (moderate depression). Her score in the Personal Uniqueness Scale elaborated by the author was equal to 3 points out of 20 which means a very poor result in PU experience.

The author has conducted ten weekly sessions with the client in September-November 2013. Home assignments were offered at the end of each session. First of all, I gave the client some information concerning a new therapy, using some historical analogies from the Ancient Greek "daemon" concept, humanistic approaches to a person's inner potential as well as Jungian Self. Then I asked N. if she could recall some important life situations in which she had a deep inner conviction of being right. The client remembered two of them: meeting her future husband and getting acquainted with him for the first time as well as her decision to visit dancing classes. She reported that at the start of both situations she heard a kind of inner voice and then (after making the right choice) she felt profound joy and a kind of liberation in her hands and body.

As long as $\mathrm{N}$. was a musician it was easy for her to understand the concept of Personal Uniqueness and feel it inside her body. It was located in the medium of her chest and was felt like a kind of pleasant "density". The next two sessions N. was making her PU "stronger" and was gradually learning to appreciate her "inner treasure" which was much more important for her than any stressful event coming from the outside. She started recollecting more situations in which she had made the "right" or the "wrong" choices. In the latter cases she hadn't listen to her "first" and authentic calling but yielded to the "second", "social" voice. After some time she was beginning to feel regret for her wrong decision but as a rule it was too late.

By the middle of the therapy course $\mathrm{N}$. was also taught how to practice the Progressive Muscular Relaxation techniques (E. Jacobson). Step by step, she could expand her sensations of "pleasurable density" onto her hands. She was told that at the time of her (future) musical performance she would be able to choose between "feeling right", joy and liberation in her hands. In any stress situations (or before them) N. was to touch the place in her body where "pleasurable density" was located and tell herself that the ideal part is still with her. Her Personal Uniqueness will help her to make the right choice in any "external" situation and cope with it. Some role-playing techniques modeling client's typical distresses had been mastered by that time.

On the 8th session N. was encouraged to bring her violin and play for the psychologist and his friends feeling at the same time pleasurable density in her chest, liberation in her hands and joy in her soul. As far as the performance was successful, N. was encouraged to recommence her musical training with the new feelings of joy, liberation and "being right". She turned down the "wrong" idea of working at the IT company and decided to apply for a more appropriate job connected with music. Since then she could easily stop the unpleasant sensations in her hands (when and if they were going to appear in the situations of a strong "social pressure") and substitute them for the feelings of "being right", liberation and joy.

In a month after PUT termination (December 2013) N. was feeling well and was eagerly preparing for her new work at the musical school. Her score at BDI (5 points) showed no signs of clinical depression, while her score at the PU scale was equal to 11 points thus corresponding to the average level of a healthy adult.

\section{Brief Recommendations}

Since PUT is a relatively new kind of therapy and can be applied with a broad range of clients including healthy people, we can't presently give the detailed instructions for any category of the users.

As a rule, an unprepared client needs some time to perceive the concept of Personal Uniqueness and its presence inside her. During this period, she can imagine PU metaphorically for example as a source of inner heat or glow. She can remember the situations and problems with which she has coped in her own unique way. She is also motivated to speak about the best qualities she has inherited from her parents. All these exercises facilitate the progress from "negative" to "positive" states of mind. The initial "contact" with PU may be successfully established in a trance state with highly suggestible clients (therapist should manage corresponding techniques).

Metaphorically speaking, a client ought to consider herself a kind of a "servant" to her ideal part. She should help her Personal Uniqueness in anyway, thus getting opportunities for her own growth and development. The newly created (deliberate) construct demands corresponding activity - the proof of PU existence from now on. We offer the client to feel herself as a hero in her own life, moving 
along the road which leads to happiness.

In the PUT process, the client learns to construct, be aware of and listen to her ideal part, thus gaining wisdom and psychological resources, temporary changing the focus from "external and bad" to "internal and good" (as well as to "external and good" in future). As far as the person's best qualities are projected onto her Personal Uniqueness, she becomes ready to start the road of her inner excellence eudaimonic life. The "right" (perhaps even righteous) way of living and acting (which helps by the way to overcome symptoms) is considered as a means of PU strengthening and its further realization. The client is taught to behave "ideally" for the sake of her ideal part. Such person begins to learn from oneself not from different "authorities".

After the initial contact with PU was established the therapist and the client work out the home tasks which should be fulfilled until the next session. The client may gradually return to the activity which enabled her to reach maximum self-expression in her past or to start some new one. The concomitant feeling of "being right" is considered to be one of the important criteria for everyday living. Any activity of the client directed towards ordinary problems negotiation is welcomed by the therapist and regarded as PU strengthening.

\section{Conclusions}

We have presented the first system that can be "officially" labeled as belonging to positive psychotherapy in all its peculiarities. At present we do not give an exhaustive account regarding particular details suitable for specific therapeutical situations. Our main purpose in this article was to make the first step - represent the theoretical grounds sufficient for introducing the new method with its specific directivity. PUT constant probation brings fresh empirical results which we intend to summarize and discuss in our future publications. One of its merits is an easy connection with other necessary therapies (see 5. PUT Application...).

In any case, when appropriately used, PUT can bring no harm since it concentrates exclusively on the positive side of a person's being. Such conditions are as well favorable for the therapist's own PU liberation in his professional activity, thereby making the right example for his client.to only one return at the end of a paragraph. Do not add any kind of pagination anywhere in the paper. Do not number text heads-the template will do that for you.

\section{References}

[1] Levit, L.Z. (2010). Schastje ot uma - 3. [Happiness of the Mind-3. (3rd ed.)]. Minsk: Para la Oro.

[2] Levit, L.Z. (2011a). Formula schastja. [Formula of Happiness]. Minsk: Varaksin.

[3] Levit, L.Z. (2011c). Lichnostno-orientirovannaja kontceptsija schastja: zhizn vo imja sebja. [Person-Oriented Conception of Happiness: Life in the Name of Oneself].
Minsk: Varaksin.

[4] Levit, L.Z. (2012 a). LOKS: mezhdu Frejdom, Jungom I Maslow. [POCH: Between Freud, Jung and Maslow]. Minsk: Varaksin.

[5] Levit, L.Z. (2013 d). Unikalnyi potentcial, samorealizatsija, schastje. [Uniqie Potential, Self-Realization, Happiness]. Saarbrucken: Lambert Academic Publishing.

[6] Levit, L.Z. (2009). Psihologija schastja: Monte-Karlo ili papa Karlo? [The Psychology of Happiness: "Monte Carlo" or "Father Carlo"?]. Psychotherapy \& Clinical Psychology, №2. P. 42.

[7] Levit, L.Z. (2011b). Psihologija schastja: vozmozhnost novoj paradigmy. [The Psychology of Happiness: the Possibility of a New Paradigm]. In S. I. Kudinov (ed). Aktualnyje problemy etnicheskoi I socialnoj psihologii. [Actual Problems of Ethnic and Social Psychology]. Moscow: RUDN. Pp. 319-323.

[8] Levit, L.Z. (2012 b). Lichnostno-orientirovannaja kontceptsija schastja: kratkaja istorija. [Person-Oriented Conception of Happiness: the Brief History]. Psychology and Psychotechnics, №8. Pp. $78-86$.

[9] Levit, L.Z. (2012 e). Happiness: Person-Oriented Conception. International Journal of Advances in Psychology, №1(3). Pp. $46-57$.

[10] Levit, L.Z. (2013 a). Person-Oriented Conception of Happiness: Between Freud, Jung and Maslow. International Journal of Economy, Management and Social Sciences. August. №2 (8). Pp. 576 - 584.

[11] Levit, L.Z., \& Radchikova, N.P. (2012). Lichnostno-orientirovannaja kontceptsija schastja: teorija I praktika. [Person-Oriented Conception of Happiness: Theory and Practice (part 1)]. The National Psychological Journal, №7. Pp.10-19.

[12] Ryan, R. M., Huta, V., \& Deci, E. L. (2008). Living well: A self-determination theory perspective on eudaimonia. Journal of Happiness Studies, №9, Pp.139-170.

[13] Ryff, C. D., \& Singer, B. H. (2006). Know Thyself and Become What You Are: A Eudaimonic Approach to Psychological Well-Being. Journal of Happiness Studies, №9, Pp. 13-39.

[14] Waterman, A. S., Schwartz, S. J., \& Conti, R. (2008). The Implications of Two Conceptions of Happiness (Hedonic Enjoyment and Eudaimonia) for the Understanding of Intrinsic Motivation. Journal of Happiness Studies, №9, Pp. 41-79.

[15] Diener E., Biswas-Diener R. (2008). Happiness. Blackwell Publishing.

[16] Myers, D.G. (2002). The Pursuit of Happiness. USA: Quill.

[17] Waterman, A.S. (1984). The Psychology of Individualism. New York: Praeger.

[18] Kringelbach, M.L., \& Berridge, K.C. (2009). Towards a functional neuroanatomy of pleasure and happiness. Trends in Cognitive Sciences, Vol.13. №11. Pp.479-488.

[19] Kringelbach, M.L., Berridge, K.C. (2010). The functional neuroanatomy of pleasure and happiness. Published on June 25, 2010. www.discoverymedicine.com. 
[20] Levit, L.Z. (2013 c). Lichnostno-orientirovannaja kontceptsija schastja: novaja sistemnaja paradigma [Person-Oriented Conception of Happiness: New Systemic Paradigm]. Pedagogical Education in Russia, №1. Pp. 102 111.

[21] Prochaska, J.O., \& Norcross, J.C. (2003). Systems of Psychotherapy. USA - UK: Thomson Learning.

[22] Levit, L.Z. (2012 c). Terapija lichnostnoi unikaljnostju: teoreticheskoije obosnovanije projekta. [Personal Uniqueness Therapy: the Theoretic Foundation of the Project]. Tendencies and Innovations in Contemporary Science. The Materials of the 3rd Scientific-Practical Conference (the reports). Krasnodar. P. 47.

[23] Levit, L.Z. (2013 f). Lichnostnaya unikalnost klienta kak osnova dlia terapii. [Personal Uniqueness of a Client as the Basis for Therapy]. Psychology and Psychotechnics, №6. Pp. $584-590$.

[24] Norton, D. (1976). Personal Destinies. Princeton: Princeton University Press.

[25] Huxley, A. (1990). The Perennial Philosophy. New York: HarperCollins Publishers.

[26] Rogers, C. R. (2001). Klientcentrirovannyj podhod $\mathrm{v}$ psihoterapii. [Client-Centered Approach in Psychotherapy]. Voprosy Psihologii, №2. Pp. 48 - 58.

[27] Freud, Z. (1991). Po tu storonu principa naslazhdenija. [Beyond the Pleasure Principle]. Tbilisi: Merani.

[28] McWilliams, N. (1994). Psychoanalytic Diagnosis. New York: The Guilford Press.
[29] Peseschkian, N. (1987). Positive Psychotherapy: Theory and Practice of a New Method. Heidelberg: Springer.

[30] Levit, L.Z. (2013 e). Egoism, lichnostnaya unikalnost, narcissism: shodstvo i razlichija. [Egoism, Personal Uniqueness, Narcissism: Common and Different Features]. Pedagogical Education in Russia, №4. Pp. 212 - 225.

[31] Shamshikova, O.A., \& Klepikova, N.M. (2010) Oprosnik "Narcissicheskije cherty lichnosti" [The Inquiry "Narcissistic Personality Traits"]. Psychological Journal. Vol. 31, №2. Pp. $114-128$.

[32] Wong P.T.P. (2012) Toward a Dual-Systems Model of What Makes Life Worth Living. The Human Quest for Meaning ( $2^{\text {nd }}$ ed.). New York: Routledge. Pp. $3-22$.

[33] Armstrong, K. (2012). The Case for God. London: The Bodley Head.

[34] Frankl, V. (1969). The Will to Meaning. New York: Plume.

[35] Seligman, M.E.P. (2012). Flourish. New York: Free Press.

[36] Levit, L.Z. (2013 b). Trening i diagnostika komponentov evdemonicheskoi aktivnosti individa [Training and Diagnostics of Individual Eudaimonic Activity Components] Actual problems of the humanitarian, social and economic sciences / Materials of the $7^{\text {th }}$ scientific and practical conference. Part 2. Saratov-Volsk: Nauka. Pp.72-79.

[37] Levit, L.Z. (2012 d). Lichnostno-orientirovannaja kontceptsija schastja I oprosnik ZULUREG. [Person-Oriented Conception of Happiness and the «Zulureg Inquiry»]. Vestnik Obrazovanija $i$ Nauki. Pedagogika. Psihologija. Medicina. №2 (4). Pp. 38 - 48. 